\title{
Older men and social activity: a scoping review of Men's Sheds and other gendered interventions
}

\author{
CHRISTINE MILLIGAN*, DAVID NEARY†, SHEILA PAYNE $\ddagger$, \\ BARBARA HANRATTY§, PAMELA IRWIN* and \\ CHRISTOPHER DOWRICK\|
}

\begin{abstract}
Finding ways of improving the health and wellbeing of older men is an important challenge for public health. This review aimed to assess evidence for the effects of Men's Sheds and other gendered social activities on the health and wellbeing of older men, and to consider their effective components and theoretical frameworks. A scoping review using standardised search criteria and terms identified 31 relevant papers of sufficient quality for inclusion. Analysis was informed by guidance on interpretative and narrative synthesis and a quality assessment tool designed for reviewing disparate data from different disciplines and research paradigms applied. The review found some limited evidence that Men's Sheds and other gendered social activities may have impact on the mental health and wellbeing of older men, but little evidence of the impact on physical health. Qualitative data provided valuable insights into how and why complex psycho-social activities can affect participants, but there was a lack of longitudinal evidence drawing on validated health and wellbeing measures. Key components of successful interventions included accessibility, range of activities, local support and skilled co-ordination. A variety of theoretical frameworks were employed. As yet, there is no conclusive evidence that Men's Sheds and other gendered interventions confer health and wellbeing benefits on older men. Studies in this field to date are few and of variable quality. Larger and more robust mixed-methods studies, including randomised designs, are needed.
\end{abstract}

KEY WORDS - older men, social isolation, wellbeing, interventions, scoping review.

* Centre for Ageing Research, Faculty of Health and Medicine, Lancaster University, UK.

$\uparrow$ Public Health and Public Policy, Liverpool University, UK.

$\$$ Division of Health Research, Lancaster University, UK.

$\S$ Health Sciences, University of York, UK.

II Psychological Sciences, Liverpool University, UK. 


\section{Christine Milligan}

\section{Introduction}

Whilst population ageing is an almost universal phenomenon, women, on average, outlive men across all population groups and cultures (Salomon et al. 2012; Wang et al. 2012). Yet recent data for both the United Kingdom (UK) and the European Union more widely demonstrate that this gap in gendered life expectancy is closing (Davidson 2013; Eurostat 2012). Despite this shift, much of the literature on men's health is dominated by negative portrayals of men's life expectancy, in which men are constructed as being more likely to lead riskier lifestyles than women and less likely to make optimal use of health-care services (White et al. 2011:41). Premature mortality amongst men is often attributed to unhealthy lifestyle choices, including those related to alcohol and tobacco. Finding ways of improving the health and wellbeing of older men thus presents an important challenge for public health.

Linked to debates about health and gender in later life is a growing concern about the health impacts of loneliness and social isolation. At its simplest, social isolation can be defined as an absence of other individuals (Hawton et al. 2011; Victor, Scambler and Bond 2009), whilst loneliness is viewed as the psychological counterpart of social isolation (Shankar et al. 2011 ). Social isolation, loneliness and stressful social ties are associated with poor physical and mental health, higher risk of disability, poor recovery from illness and early death (Cacioppo et al. 2011; Luanaigh and Lawlor 2011 ; Masi et al. 2011 ). Indeed, amongst older adults, the effect of social isolation and loneliness on mortality is believed to be of similar size to that of cigarette smoking (Holt-Lunstad, Smith and Layton 2010). Whilst loneliness is not an inevitable consequence of lone dwelling, those who do live alone are at greater risk of social isolation. In the UK alone, between 5 and 7 per cent of middle-aged and older people experience severe or persistent loneliness, with the number of older men who live alone reaching around one million for the first time (Steffick 2000; Victor, Scambler and Bond 2009).

Older women have tended to attract more scholarly attention than older men, hence there is still something of an academic 'blind spot' in research around older men in comparison to their female counterparts (Arber et al. 2003; Fennell and Davidson 2003; Fleming 1999). Yet social isolation is common amongst older men, particularly those who live alone or experience mood or cognitive problems (Illiffe et al. 2007). Finding activities and interventions that can successfully address the problems of social isolation amongst older men is thus an important health challenge. Older men not only find it harder than women to make friends late in life, they 
are also less likely to join community-based social groups that tend to be dominated by women. They are known to use fewer community health services than women, and are less likely to participate in preventive health activities (Suominen-Taipale et al. 2006; White et al. 2011). This combination of need and lower rates of engagement with services has prompted the public and voluntary sectors to look to develop a range of social activity interventions specifically targeted at older men.

Social activity in a variety of forms has long been recognised as beneficial to health, particularly among older people. House, Landis and Umberson (1988), for example, highlighted the increased risk of death among those people with a low quantity, and sometimes low quality, of social relationships. Work underpinned by social activity theory for older people has thus hypothesised that health and wellbeing is promoted by high levels of participation in social and leisure activities and role replacement (Betts Adams, Leibbrandt and Moon 2011). A number of reviews have thus sought to consolidate knowledge on the links between social activity, health and wellbeing (e.g. Cattan et al. 2003; Dickens et al. 2011; Findlay 2003). Betts Adams, Leibbrandt and Moon (2011), in particular, found a diverse literature around 42 studies that showed positive associations between social activity and health and wellbeing. A systematic review by Cattan et al. (2003) further found that group activities with an educational or support input were most likely to be effective in alleviating social isolation amongst older people. Indeed, such is the impact of social activity on health and wellbeing, that a meta-analysis of $14^{8}$ studies undertaken by HoltLunstad, Smith and Layton (2010) found a $5^{\circ}$ per cent increase in the overall odds of survival as a function of social relationships. Drawing on the outcomes of a large-scale study of nearly 17 ,ooo adults in North America, Pantell et al. (2013) were also led to conclude that as a predictor of mortality, the strength of social isolation is similar to that of well-documented clinical risk factors (although it is worth noting that the data did not allow the authors to account for the effect of social position on mortality).

Developing interventions to promote social activity among older men, particularly those who are lonely or socially isolated, has proven to be a difficult task (Greenfield and Marks 2004; Milligan et al. 2014). One recent and rapidly developing social activity intervention for older men is that of the Men's Sheds movement. This has spread from Australia to several parts of the Anglophone world including the UK and Ireland (Wilson and Cordier 2013). Sheds provide a communal space for older men to meet, socialise, learn new skills and voluntarily take part in practical activities with other men. Much of this activity is focused around woodwork but Sheds can cover a wide range of activities, stretching from engineering 


\section{Christine Milligan}

to model railways and the making of musical instruments. They can engage men in informal adult learning activity, or provide health-related information or signposting to relevant services (Milligan et al. 2012). Sheds may also have a wider benefit to the local community in terms of engaging with, and providing services for, individuals and groups within that community (Carragher 2013). Many of the Sheds are member led or are supported by voluntary-sector organisations, a few are supported by charitable donations from the business sector. All, however, are tailored to their local context and, hence, are not standardised. Whilst Shed members may not necessarily recognise or welcome the notion of Sheds as an intervention, we suggest that given their broad aims to improve physical, emotional, social and spiritual health and wellbeing, and the increasing recognition and support of Sheds within public health initiatives, Sheds can be considered a complex intervention.

Sheds have captured the public imagination. Over $75^{\circ}$ Men's Sheds now exist across Australia (Cordier and Wilson 2014), with more than 50,ooo older men attending on a regular basis. Men's Sheds have attracted at least Aus dollars 750,00o between 2010-2013 from the Australian State Government with further support from local sources (Australian Government 2015). A similar, but more modest, pattern of growth and funding has developed across the UK (Milligan et al. 2014) and Ireland (Carragher 2013).

However, before advocating gender-based activity interventions for older men, several issues need to be clarified. Firstly, we need a better understanding of what the literature tells us about conceptual and measurement differences, reflecting the various academic disciplines that have conducted research in this area. Importantly, to what extent does this enable us to compare and synthesise across studies? Secondly, to what extent does the literature enable us to determine the direction of causality between activity and health? Are older men more likely to be healthy because of the activities they participate in, or are they more active due to the good health they enjoy? Thirdly, there are unresolved questions around various types of activities and gender, with older men appearing to benefit from physical activities and solitary hobbies much more than older women (Betts Adams, Leibbrandt and Moon 2011).

In the light of these issues, it is important to have a clear understanding of what the evidence base tells us about the role and impact of gender-based activity interventions on the health and wellbeing of older men. Whilst Sheds are perhaps the fastest growing social activity interventions for older men, we have also seen the emergence of a number of other social activity interventions designed for older men in recent years. In terms of their descriptive features, these other gendered interventions are clearly 
TAB LE 1. Search strategy and actions

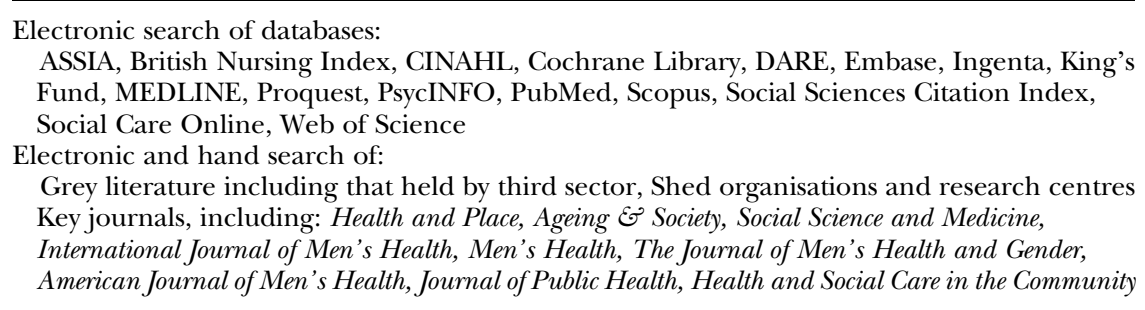

more diverse than Men's Sheds. A cooking club for older men, a community allotment and a 'Gentleman's Club' in a residential care setting are clearly different forms of social activity intervention but, importantly, they are all defined by having older men as participants in voluntary social activity that is theoretically intended to improve their health and wellbeing. Furthermore, as they share this essential characteristic, some inferences on adequate causal links can be made (Buss 1999). In this paper, we thus draw on the outcomes of a high-quality scoping review of the existing published literature on Men's Sheds and other gendered interventions that was designed to address the following questions:

- What are the effects on the physical health of older men?

- What are the effects on the mental health of older men?

- What are the effects on the wellbeing of older men?

- What are the effective components of interventions?

- What theoretical frameworks were employed?

\section{Methods}

The scoping review of the available studies on Men's Sheds and on other forms of gendered interventions for older men aimed to compare and contrast the evidence of effects on the health and wellbeing of older men.

Our search strategy, incorporating electronic and hand searches of publications from 1990 to 2013 , is set out in Table 1. Grey literature searches included the websites of a number of age-related and male-orientated voluntary organisations in the UK, Australia, New Zealand, Ireland, Canada and the United States of America (USA). The websites of appropriate Government departments in these countries were also searched along with the OpenGrey Repository (formerly OpenSIGLE) for relevant literature. The first $5^{\circ}$ results from combinations of older men and interventions 


\section{TABLE 2. Search terms}

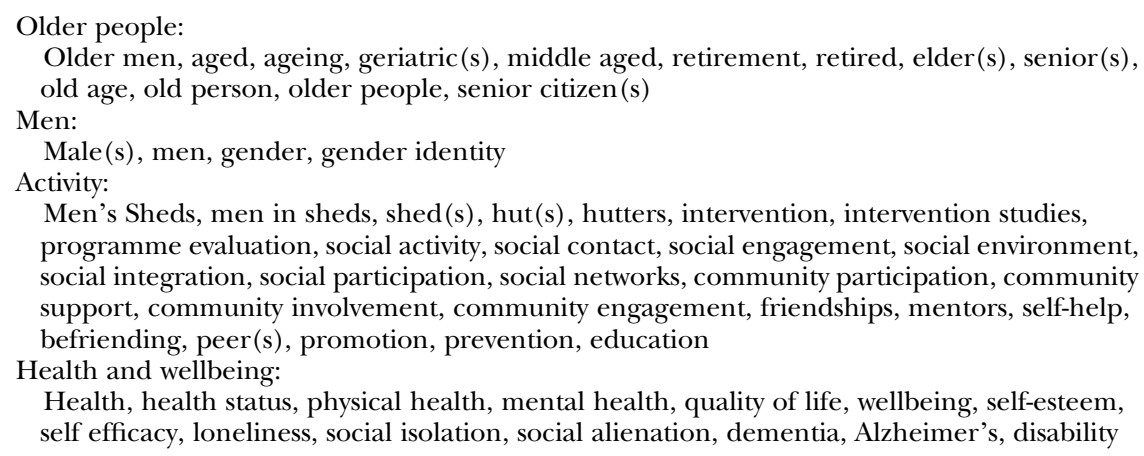

were also screened for possible inclusion. Initial screening and searches demonstrated a declining relevance to the review topic beyond the first 40 results, hence a pragmatic decision was made to limit screening to the first $5^{\text {o. }}$

The following search terms and all their variations, as set out in Table 2, were incorporated into a search strategy tailored to each database, drawing on specialist librarian support.

A clear set of inclusion and exclusion criteria was discussed and agreed by the research team prior to undertaking the searches. Inclusion criteria included all forms of publications containing original empirical data on interventions that provided an opportunity for older men to meet together face to face in a specified place for social activities, learning and teaching, or the receipt of advice. Included studies needed to contain some measure of how the intervention impacted on health, quality of life or wellbeing of participants or their families. No study design was excluded.

Exclusion criteria included studies that solely considered interventions or activities where the primary focus is sport or leisure activities in clubs or religious activity, formal education, paid work or volunteering, or part of statutory service provision (such as local authority day centres) or disease-specific support groups. Studies that reviewed interventions not specifically designed for older people were also excluded.

The search strategy aimed to include all relevant studies of Men's Sheds and other gendered activity interventions that were exclusively or predominantly focused on older men. In line with current provider policy, an older man was defined as someone over the age of $5^{\circ}$ years. Initially, a predominant focus was interpreted as a study with a sample that contained threequarters of the total being older men, but at an early stage it was evident 


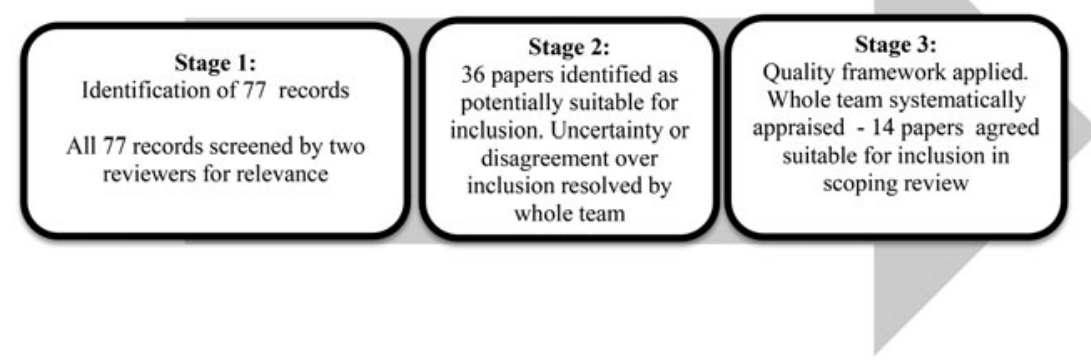

Figure 1. Search process for Men's Sheds literature.

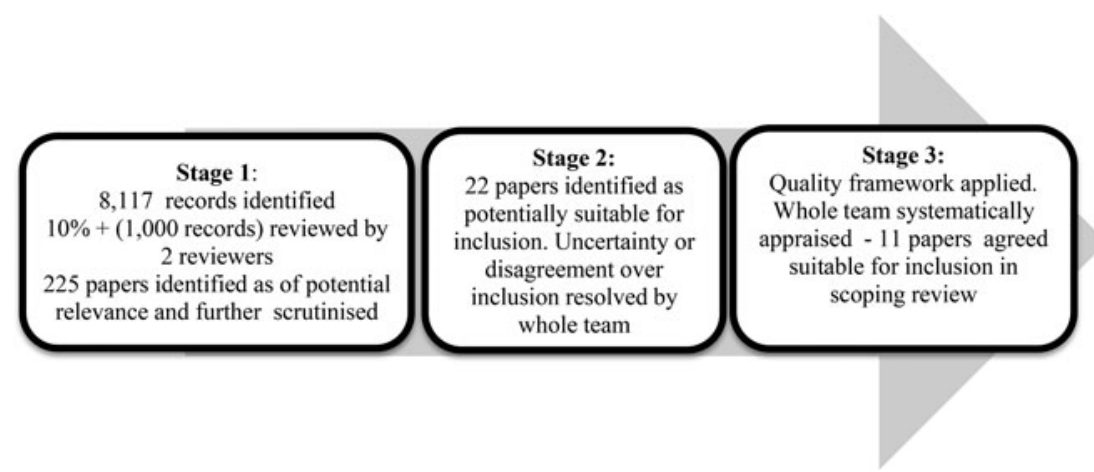

Figure 2. Search process for other gendered activity interventions literature.

that such a stringent approach would limit the number of studies included in the review with the loss of potentially valuable insights. A pragmatic decision was taken to include studies where older men formed the majority of the sample. This was defined as 5 o per cent plus one of participants in the sample population, regardless of its size, and where there was clear data from only older males. Figures 1 and 2 detail the search and screening process used for both the Men in Sheds literature and the literature focusing on other gendered activity interventions for older men.

Our search included electronic and manual searches, including the checking of bibliographies of papers as well as relevant conference papers and presentations. In addition, individual contact was made with all Men's Sheds projects in the UK as well as experts in Australia to identify further potential sources. The relatively small number of Men in Shed sources $(\mathrm{N}=77)$ meant it was possible for all of these sources to be screened by two reviewers. Electronic searches for the 'other gendered activity intervention' sources however revealed 8,1 16 records, hence all of these records 
were screened by one reviewer (DN) and a 10 per cent randomised sample $(\mathrm{N}=1, \mathrm{Ooo})$ was screened by a second reviewer $(\mathrm{PI})$ to ensure accuracy and consistency in the application of the inclusion and exclusion criteria. PI took the lead for work around Men's Sheds, with DN taking the lead for work around other gendered interventions. Where uncertainty or disagreement around inclusion/exclusion occurred, a final decision was made by the whole research team. The whole research team also reviewed and agreed the final set of papers for inclusion.

\section{Quality assessment and data extraction}

We used the tool developed by Hawker et al. (2002) to appraise the quality of the studies in this scoping review. The tool uses a scale of 1 to 4 across nine domains to assess methodological rigour and clarity of reporting and was independently applied to the studies by both reviewers. The quality scores ranged from 13 to 34 out of a possible total of 36 , with a median score of 27 , with a high degree of agreement between the reviewers and the wider research team on the aggregate scores for the studies included in both reviews. These scores are included in Table 3 to inform the reader, but they played no part in any decisions to include or exclude individual studies. Our review encompassed qualitative and quantitative studies, and there are very few quality assessment tools that are applicable to such a wide range of methods. This tool has been widely used in UK research, though we do acknowledge that it has not undergone extensive validation.

A common data extraction tool, covering 18 substantive domains ranging from location and methodology through intervention and sample description to findings and limitations, was developed and tested by both reviewers on three studies from each review. This was independently applied to the studies of Men's Sheds and gendered interventions. Minor differences were reconciled through discussions during and after data extraction.

\section{Data analysis and synthesis}

Reviews were informed by the Medical Research Council guidance on the development and evaluation of complex interventions (Craig et al. 20o8; Medical Research Council 2008) and the Cochrane Collaboration guidelines for reviews on health promotion and public health interventions (Armstrong et al. 2007). The majority of the studies included were either qualitative studies, cross-sectional surveys or used a combination of these methods. There were no intervention studies, and only three of the Men's Sheds studies included collected data at more than one point in time. This means that all the research discussed in this paper falls into 
T А В L E 3. Summary and quality (QA) scores of included studies

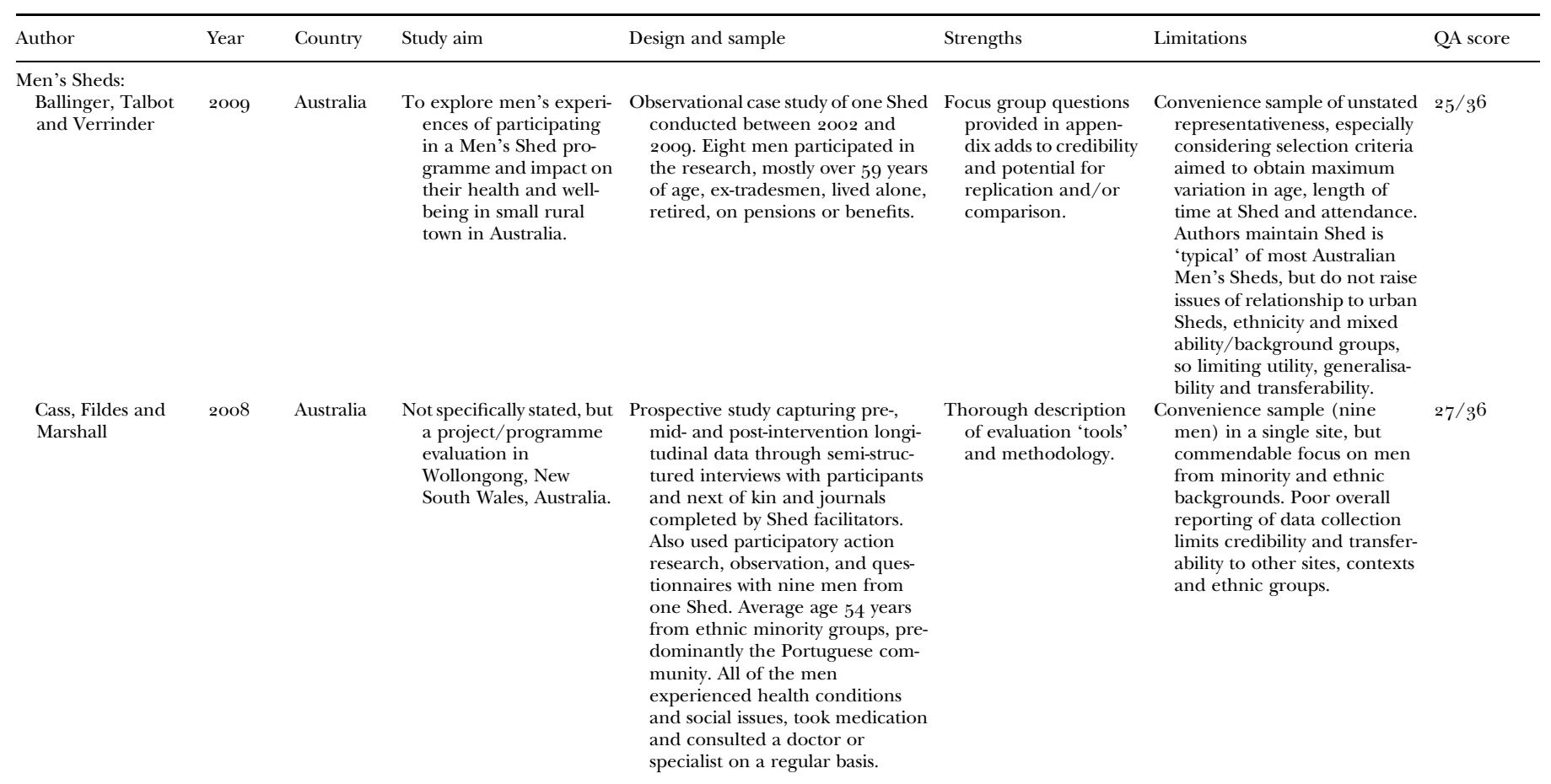


TA вLE 3 . (Cont.)

\begin{tabular}{|c|c|c|c|c|c|c|c|}
\hline Author & Year & Country & Study aim & Design and sample & Strengths & Limitations & QA score \\
\hline Golding et al. & 2006 & Australia & $\begin{array}{l}\text { To conduct (the first) } \\
\text { comprehensive survey } \\
\text { of participants in } \\
\text { Men's Sheds in } \\
\text { Victoria, Australia }\end{array}$ & $\begin{array}{l}\text { Quantitative survey of active Men's } \\
\text { Sheds. Ten surveys sent to } 27 \\
\text { active Victorian Men's Sheds; } 154 \\
\text { surveys returned from } 22 \text { Sheds; } \\
39 \% \text { of participants attended a } \\
\text { Shed managed by an education- } \\
\text { type organisation; } 61 \% \text { of partici- } \\
\text { pants were located in health-type } \\
\text { organisations; } 42 \% \text { of participants } \\
\text { attended metropolitan Sheds; } \\
58 \% \text { attended non-metropolitan } \\
\text { Sheds. }\end{array}$ & $\begin{array}{l}\text { First attempt to capture } \\
\text { broad demographic } \\
\text { profile of men } \\
\text { attending a Men's } \\
\text { Shed in Australia, } \\
\text { with quantitative and } \\
\text { some qualitative } \\
\text { data. }\end{array}$ & $\begin{array}{l}\text { Authors note that though the } \\
\text { survey response was high and } \\
\text { the survey was inclusive of } \\
\text { most active Men's Sheds in } \\
\text { Victoria, respondent } \\
\text { numbers relatively small, } \\
\text { impacting on accuracy and } \\
\text { confidence levels when data } \\
\text { are broken into several cat- } \\
\text { egories. Survey deliberately } \\
\text { excluded the relatively small } \\
\text { number of female partici- } \\
\text { pants who are active members } \\
\text { of some men's and particu- } \\
\text { larly 'community' Sheds. No } \\
\text { details of selection/stratifica- } \\
\text { tion of specific Sheds in } \\
\text { sample, and though } 26 \text { vari- } \\
\text { ables exist, power calcu- } \\
\text { lations/confidence levels are } \\
\text { not noted. }\end{array}$ & $29 / 36$ \\
\hline $\begin{array}{l}\text { Golding, Brown } \\
\text { and Foley }\end{array}$ & 2007 & Australia & $\begin{array}{l}\text { To illustrate some theor- } \\
\text { etical and practical } \\
\text { implications and } \\
\text { benefits of reciprocal } \\
\text { workshop-based men- } \\
\text { toring relationships } \\
\text { involving men of } \\
\text { different ages }\end{array}$ & $\begin{array}{l}\text { Mixed-methods study (on-site inter- } \\
\text { views and survey) in sample of } 24 \\
\text { Sheds providing a social and } \\
\text { therapeutic function across five } \\
\text { Australian states. Sample centred } \\
\text { on young people, war veterans } \\
\text { and men in aged residential care. } \\
\text { Focus is on theoretical and prac- } \\
\text { tical implications and benefits of } \\
\text { reciprocal workshop-based men- } \\
\text { toring relationships involving men } \\
\text { of different ages. }\end{array}$ & $\begin{array}{l}\text { Provides qualitative } \\
\text { insights into how the } \\
\text { Shed model can } \\
\text { accommodate } \\
\text { special groups with } \\
\text { varying needs. }\end{array}$ & $\begin{array}{l}\text { Sub-samples from large Golding } \\
\text { et al. (2007) survey. Much of } \\
\text { introduction and background } \\
\text { relates to older participants, } \\
\text { but primary focus is utility of } \\
\text { the Men's Shed model for } \\
\text { young people (male and } \\
\text { female) and war veterans, } \\
\text { rather than those aged over } \\
65 \text { years. Though emphasis } \\
\text { on direct effects of Sheds to } \\
\text { health and wellbeing for ex- } \\
\text { military and older care reci- } \\
\text { pients, no objective health } \\
\text { measures used. }\end{array}$ & $18 / 36$ \\
\hline
\end{tabular}

etical and practical

implications and

toring relationships

nvolving men of 

ing styles employed in the motivations and experiences of the mainly older men who frequent them.

To explore the gendere roles associated with men's informal learning, in particular the role of women as coordinators and participants in community organisations where men comprise the significant majority of participants.

To assess links between participation and learning with health and wellbeing in a range of age- and disability-related community organisation directly comparable with Men's Sheds.
Mixed-methods study (on-site inter- First comprehensive views and survey) in sample of 24 Sheds providing a social and therapeutic function across five Australian states. Sample centred on young people, war veterans and men in aged residential care. Focus on learning styles employed in Men's Sheds, motivations and experiences of the mainly older men who frequent them.

Mixed-methods study (on-site inter- Provides qualitative views and survey) in sample of 24 Sheds providing a social and therapeutic function across five Australian states. Sample centred on young people, war veterans and men in aged residential care. Focus is on interview data to identify the status of women engaged in Men's Sheds.

Mixed-methods study with 34 ageand disability-related community organisations directly comparable with Men's Sheds including adul and community education, sporting, religious, indigenous and cultural, fire and emergency services, in six sites across Western Australia. Survey followed by

group interviews with focus on links between participation and learning with health and wellbeing.
Shed selection was based on convenience (not randomistion) and skewed towards the 'early adopter' states and locations closer to cities for ease of researcher access. Respondent selection was possibly biased by key informants choosing survey participants.

As the research question is potentially sensitive and conroversial, the study does not provide adequate details about: (a) theoretical base, some background but not fully contextualised - effort to ground in (limited) theory are not well related to research question; (b) ethica precautions; (c) findings, results lack clear presentation and explanation and do not progress logically from the findings.

Mixed-methods study Men's Sheds were minor subsample of other gendered interventions - the only Shed included in the study was grouped with a Masonic Lodge with concomitant difficulty in differentiating intervention-specific findings.

incorporating quantitative survey interviews. 
TAble $3 \cdot$ ( Cont.)

\begin{tabular}{|c|c|c|c|c|c|c|c|}
\hline Author & Year & Country & Study aim & Design and sample & Strengths & Limitations & QA score \\
\hline Golding et al. & $2009 b$ & Australia & $\begin{array}{l}\text { To assess links between } \\
\text { participation and } \\
\text { learning with health } \\
\text { and wellbeing in a } \\
\text { range of age- and dis- } \\
\text { ability-related commu- } \\
\text { nity organisations } \\
\text { directly comparable } \\
\text { with Men's Sheds. }\end{array}$ & $\begin{array}{l}\text { Mixed-methods study with survey } \\
\text { distributed to participants, fol- } \\
\text { lowed by group interviews with } \\
\text { older men who attended range of } \\
\text { age- and disability-related com- } \\
\text { munity organisations directly } \\
\text { comparable with Men's Sheds, e.g. } \\
\text { adult and community education, } \\
\text { sport, religious, indigenous and } \\
\text { cultural, fire and emergency ser- } \\
\text { vices. Designed to assess links } \\
\text { between participation and learn- } \\
\text { ing with health and wellbeing. }\end{array}$ & $\begin{array}{l}\text { Mixed-methods study } \\
\text { incorporating a } \\
\text { quantitative survey } \\
\text { and qualitative } \\
\text { interviews. }\end{array}$ & $\begin{array}{l}\text { Men's Sheds were a minor sub- } \\
\text { sample of other gendered } \\
\text { interventions. Only two Sheds } \\
\text { were clearly identified as } \\
\text { Men's Sheds and a third was } \\
\text { classified as a community } \\
\text { work-shed. }\end{array}$ & $32 / 3^{6}$ \\
\hline Graves & 2001 & Australia & $\begin{array}{l}\text { To determine 'the magic } \\
\text { of the Shed' - why men } \\
\text { go to the Shed, barriers } \\
\text { to attendance, what } \\
\text { happens at the Shed } \\
\text { and the benefits for the } \\
\text { participants. }\end{array}$ & $\begin{array}{l}\text { Mixed-methods evaluation of an } \\
\text { early Shed in Australia with men } \\
\text { aged } 4^{8-70} \text { using focus groups, } \\
\text { questionnaires and the PRECEDE } \\
\text { framework to assess health edu- } \\
\text { cation needs in a community } \\
\text { setting. Aimed at exploring why } \\
\text { men go to the Shed, barriers to } \\
\text { attendance, what happens and the } \\
\text { benefits for the participants. }\end{array}$ & $\begin{array}{l}\text { Possibly the first evalu- } \\
\text { ation of a Men's } \\
\text { Shed and, as such, } \\
\text { tried to establish a } \\
\text { baseline of organis- } \\
\text { ational success } \\
\text { factors. }\end{array}$ & - & $23 / 36$ \\
\hline
\end{tabular}


Healthbox CIC
To evaluate effectiveness of four Men's Sheds established by Age UK for inclusion of older men. the UK consisting of observation
and surveys (RAND health ques-
tionnaire) on use of health ser-
vices - some qualitative response in surveys.
To assess the effectiveness Mixed-methods retrospective evaluof the Age UK 'Men in

Sheds' pilot pro-

gramme in engaging isolated and lonely older men on low

ncomes and enhancing their quality of life and wellbeing. ation of three Men's Sheds for older men in the UK using repeat observation, focus groups and face-to-face interviews with Shed Members, Shed co-ordinators and managers. Designed to assess the effectiveness of an Age UK 'Men in Sheds' pilot programme in

engaging isolated and lonely older men on low incomes and enhancing their quality of life and wellbeing.

Most limitations centre around: 13/36 (a) self-report and related issues such as not controlling for memory loss, and poorly delimited perceptions of health; (b) composite use of the RAND scores and access to health care to make claims that lacked robustness (although raw data were available if requested); (c) limited information about background, research questions and aims, participant profiles, data analysis and limited interpretation of findings.

Rigorous evaluation utilising mixed methods and good sample size.
Limitations noted by authors primarily relate to limitation in some data collection

(outside their control) and retrospective evaluation. 
T А в LE 3 - (Cont.)

\begin{tabular}{|c|c|c|c|c|c|c|c|}
\hline Author & Year & Country & Study aim & Design and sample & Strengths & Limitations & QA score \\
\hline Misan & 2008 & Australia & $\begin{array}{l}\text { To better understand the } \\
\text { phenomenon of Men's } \\
\text { Sheds and their } \\
\text { influence on the social } \\
\text { and other determi- } \\
\text { nants of the health of } \\
\text { men, including that of } \\
\text { indigenous men, and } \\
\text { to assess whether } \\
\text { Men's Sheds offer an } \\
\text { opportunity for deliv- } \\
\text { ery of targeted health } \\
\text { promotion pro- } \\
\text { grammes for older } \\
\text { men. }\end{array}$ & $\begin{array}{l}\text { Literature review with eight detailed } \\
\text { case studies involving approxi- } \\
\text { mately } 65 \text { focus group partici- } \\
\text { pants and two (non-comparative) } \\
\text { key informant interviews in South } \\
\text { Australia. Designed to understand } \\
\text { better the influence of Sheds on } \\
\text { the social and other determinants } \\
\text { of the health of men, including } \\
\text { indigenous men; and whether } \\
\text { Sheds can deliver targeted health } \\
\text { promotion programmes for older } \\
\text { men. }\end{array}$ & $\begin{array}{l}\text { Rigorous evaluation } \\
\text { utilising mixed } \\
\text { methods, with case } \\
\text { studies provided in } \\
\text { appendices. }\end{array}$ & $\begin{array}{l}\text { Extensive and detailed (gener- } \\
\text { alised) review with explana- } \\
\text { tory rationale for sample and } \\
\text { case study/exemplar selec- } \\
\text { tion, but no information } \\
\text { about how the synthesis and } \\
\text { analysis were conducted. }\end{array}$ & $3^{2 / 3} 6$ \\
\hline $\begin{array}{l}\text { Ormsby, Stanley } \\
\text { and Jaworski }\end{array}$ & 2010 & Australia & $\begin{array}{l}\text { To explore Australian } \\
\text { older men's percep- } \\
\text { tions on participating } \\
\text { in community-based } \\
\text { Sheds. }\end{array}$ & $\begin{array}{l}\text { Small qualitative observational study } \\
\text { of two Sheds in Australia with five } \\
\text { participants aged } 67-9^{2} \text { years, } \\
\text { four married with some care } \\
\text { needs from their wife, mixture of } \\
\text { occupations but all but one } \\
\text { retired for at least } 15 \text { years. } \\
\text { Designed to explore Australian } \\
\text { older men's perceptions on parti- } \\
\text { cipating in community-based } \\
\text { Sheds. }\end{array}$ & $\begin{array}{l}\text { Offers insightful sug- } \\
\text { gestions for further } \\
\text { research. }\end{array}$ & $\begin{array}{l}\text { Restricted sample size and } \\
\text { setting with poor generalisa- } \\
\text { bility acknowledged but no } \\
\text { discussion of implications of } \\
\text { self-report in health. }\end{array}$ & $22 / 3^{6}$ \\
\hline Reynolds & 2011 & Canada & $\begin{array}{l}\text { To develop a theoretical } \\
\text { model of the processes } \\
\text { of involvement of older } \\
\text { male adults in Men's } \\
\text { Sheds in Manitoba, } \\
\text { Canada. }\end{array}$ & $\begin{array}{l}\text { Mixed-methods qualitative research } \\
\text { (interviews, field notes, quantitat- } \\
\text { ive questionnaire) with } 12 \text { older } \\
\text { men in two Sheds in Canada. } \\
\text { Designed to develop a theoretical } \\
\text { model of the processes of invol- } \\
\text { vement of older male adults in } \\
\text { Men's Sheds. }\end{array}$ & $\begin{array}{l}\text { Rigorous methodology } \\
\text { with interview proto- } \\
\text { cols provided in } \\
\text { appendices. }\end{array}$ & - & $34 / 3^{6}$ \\
\hline
\end{tabular}


Batt-Rawden and Tellnes

Drummond, M. J. 2003

Gleibs et al. 2011
Norway

$$
\begin{aligned}
& \text { a range of indoor and } \\
& \text { outdoor activities as a } \\
& \text { method of rehabilita- } \\
& \text { tion amongst adults }
\end{aligned}
$$

To evaluate the impact and older adults. tional study in Norway using semistructured interviews with convenience sample of $4^{6}$ people ( 30 men) aged $40-79$ years, most $(82 \%)$ reporting common mental disorders or muscular-skeletal limitations and all of whom participated in a range of healthpromoting group activities (hiking, gardening, physical activities along with more sedentary art and crafts) led by professionals in rehabilitation centre. Study designed to explore social characteristics, frequency and duration of attendance at group, life experiences and subjective views on quality of life.

To assess the impact of the physical activity of a walking group and its association with health, competitive masculnity with friendship and camaraderie.

and interviews with convenience sample of six men aged $58-85$ years who formed distinct part of walking group with trained fitness co-ordinator. Designed to explore views on health, ageing and masculinity using interpretative phenomenological analysis.

To assess the effectiveness Mixed-methods 'before and after' of men-only social groups in care home settings for addressing ocial isolation on study with convenience sample of 12 older men aged $70^{-}-90$ year who chose to participate in 'Gentlemen's Club' intervention in six residential care homes in the UK. Data captured at weeks 4 and 12 including composite questionnaire measuring social identity, cognitive ability and wellbeing.
Provides some useful insights into rehabilitation centre usin salutogenic approach.

Distinguishes

between impact on different groups of people.

Observational data only so changes over time not known. No comparison group to assess interventions against. Potential sample bias/observer effect regarding positive views on centre. Limited sample size and brief reporting of methods.

Theoretically informed Poorly reported observational discussion of older data from a small sample of men and masculi- older men. No comparison nity.

Phenomenology gives depth to study. group to assess intervention against.

Data gathered at two points to assess

changes in status.

Validated tools to

measure changes.

Theoretically

Small sample size with very limited diversity among participants. No comparison group to assess intervention against. Short time-frame for duration of intervention.

not made on data per se but on theory they support. 
TABLE 3 - (Cont.)

\begin{tabular}{|c|c|c|c|c|c|c|c|}
\hline Author & Year & Country & Study aim & Design and sample & Strengths & Limitations & QA score \\
\hline Gleibs $e t$ al. & 2011 & UK & $\begin{array}{l}\text { To assess the role of col- } \\
\text { lective engagement in } \\
\text { counteracting feelings } \\
\text { of confinement and } \\
\text { lack of autonomy in } \\
\text { residential care } \\
\text { settings. }\end{array}$ & $\begin{array}{l}\text { Qualitative study using short semi- } \\
\text { structured interviews with purpo- } \\
\text { sive sample of five older men aged } \\
7^{0-90} \text { years who had participated } \\
\text { in 'Gentlemen's Club' interven- } \\
\text { tion in six residential care homes } \\
\text { in Cornwall. Designed to explore } \\
\text { their views on life in residential } \\
\text { care and the 'Club' intervention. }\end{array}$ & $\begin{array}{l}\text { Provides further quali- } \\
\text { tative insights from } \\
\text { original research. } \\
\text { Provides further } \\
\text { support for claims } \\
\text { made in earlier } \\
\text { paper regarding } \\
\text { control and choice. }\end{array}$ & $\begin{array}{l}\text { Small sample size with very } \\
\text { limited diversity among par- } \\
\text { ticipants. No comparison } \\
\text { group to assess intervention } \\
\text { against. Short time-frame for } \\
\text { duration of intervention. }\end{array}$ & $27 / 36$ \\
\hline Golding et al. & $2009 a$ & Australia & $\begin{array}{l}\text { To assess links between } \\
\text { participation and } \\
\text { learning with health } \\
\text { and wellbeing in a } \\
\text { range of age- and dis- } \\
\text { ability-related commu- } \\
\text { nity organisations } \\
\text { directly comparable } \\
\text { with Men's Sheds. }\end{array}$ & $\begin{array}{l}\text { Mixed-methods study with } 34 \text { age- } \\
\text { and disability-related community } \\
\text { organisations directly comparable } \\
\text { with Men's Sheds including adult } \\
\text { and community education, sport- } \\
\text { ing, religious, indigenous and } \\
\text { cultural, fire and emergency ser- } \\
\text { vices, in six sites across Western } \\
\text { Australia. Survey followed by } \\
\text { group interviews with focus on } \\
\text { links between participation and } \\
\text { learning with health and } \\
\text { wellbeing. }\end{array}$ & $\begin{array}{l}\text { Mixed-methods study } \\
\text { with survey of } 187 \\
\text { and interviews with } \\
\text { 1oo+ older men. } \\
\text { Provides data on } \\
\text { multiple activities } \\
\text { and sites catering for } \\
\text { needs of older men. } \\
\text { Diversity allows simi- } \\
\text { larities and differ- } \\
\text { ences to emerge. }\end{array}$ & $\begin{array}{l}\text { Observational data with no } \\
\text { comparison group. } \\
\text { Insufficient sample size to } \\
\text { provide comprehensive } \\
\text { picture of learning and well- } \\
\text { being of older men. Potential } \\
\text { bias from opportunistically } \\
\text { generated interview sample. }\end{array}$ & $32 / 36$ \\
\hline Golding et al. & $2009 b$ & Australia & $\begin{array}{l}\text { To assess links between } \\
\text { participation and } \\
\text { learning with health } \\
\text { and wellbeing in a } \\
\text { range of age- and dis- } \\
\text { ability-related commu- } \\
\text { nity organisations } \\
\text { directly comparable } \\
\text { with Men's Sheds. }\end{array}$ & $\begin{array}{l}\text { Mixed-methods study with survey } \\
\text { distributed to participants, fol- } \\
\text { lowed by group interviews with } \\
\text { older men who attended range of } \\
\text { age- and disability-related com- } \\
\text { munity organisations directly } \\
\text { comparable with Men's Sheds, e.g. } \\
\text { adult and community education, } \\
\text { sport, religious, indigenous and } \\
\text { cultural, fire and emergency ser- } \\
\text { vices. Designed to assess links } \\
\text { between participation and learn- } \\
\text { ing with health and wellbeing. }\end{array}$ & $\begin{array}{l}\text { Mixed-methods study } \\
\text { with survey of } 219 \\
\text { and interviews with } \\
15 \text { o older men. } \\
\text { Provides data on } \\
\text { multiple activities } \\
\text { and sites catering for } \\
\text { needs of older men. } \\
\text { Diversity of sites and } \\
\text { activities allows simi- } \\
\text { larities and differ- } \\
\text { ences to emerge. }\end{array}$ & $\begin{array}{l}\text { Observational data with no } \\
\text { comparison group. } \\
\text { Insufficient sample size to } \\
\text { provide comprehensive } \\
\text { picture of learning and well- } \\
\text { being of older men. Potential } \\
\text { bias from opportunistically } \\
\text { generated interview sample. }\end{array}$ & $32 / 36$ \\
\hline
\end{tabular}


Hayes, Golding and Harvey

Keller et al.
2004

Australia

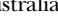

To assess the value of vol-
unteer work for older adult learning through fire and emergency service organisations in small and remote Australian towns.
To assess the health and wellbeing impacts of men-only cooking groups.
Mixed-methods study training activies at four Australia. The core of these units is often formed of older men with relatively limited level of education. Participants were aged over 5 o years and $85 \%$ men. Study designed to focus on learning and voluntary participation.

Mixed-methods study with convenience sample of older men participating in a monthly cooking club supported by a dietician in Canada. Design included questionnaire at start and end of evaluation year and semi-structured interviews. Designed to explore demographics and cooking/diet of participants, prior cooking experience, and perceived strengths and weakness of the intervention. Ten thematically analysed semi-structured interviews lasting 3o-6o minutes exploring prior cooking experience, strengths and weakness of the intervention. Dietician also kept journal. with survey of 339 and interviews with 230 older men. Links learning with health and wellbeing.

Observational data with no

Longitudinal mixedmethods study with data gathered at several points. Provides insights into older men and motivations for participation. comparison group. Insufficient sample size to provide comprehensive

picture of learning and wellbeing of older men.

Qualitative data suggested healthy diet changes but no objective measures. First data collection not at start of project. 
TAвLE 3 - (Cont.)

\begin{tabular}{|c|c|c|c|c|c|c|c|}
\hline Author & Year & Country & Study aim & Design and sample & Strengths & Limitations & QA score \\
\hline $\begin{array}{l}\text { Macdonald, } \\
\text { Brown } \\
\text { and Buchanan }\end{array}$ & 2001 & Australia & $\begin{array}{l}\text { To assess older men's } \\
\text { views on the impor- } \\
\text { tance of supporting } \\
\text { and supportive social } \\
\text { environment, difficul- } \\
\text { ties of transition from } \\
\text { paid work with loss of } \\
\text { male identity and } \\
\text { limited opportunities } \\
\text { for volunteering. }\end{array}$ & $\begin{array}{l}\text { Qualitative study with convenience } \\
\text { sample of older men attending } \\
\text { Old Men: New Ideas intervention } \\
\text { in Australia - an intervention } \\
\text { designed to address health and } \\
\text { wellbeing of older men through } \\
\text { community-based groups that } \\
\text { typically meet on a fortnightly } \\
\text { basis. Study used interviews and } \\
\text { focus groups to explore various } \\
\text { dimensions of health and well- } \\
\text { being including work and retire- } \\
\text { ment, volunteering, health and } \\
\text { social services, male culture, } \\
\text { relationships and social networks. }\end{array}$ & $\begin{array}{l}\text { Very wide-ranging } \\
\text { exploration of older } \\
\text { men's views on life, } \\
\text { health and well- } \\
\text { being. Provides } \\
\text { useful insights on } \\
\text { areas and issues that } \\
\text { are not covered in } \\
\text { other included } \\
\text { studies. }\end{array}$ & $\begin{array}{l}\text { Observational data with no } \\
\text { comparison group. Poorly } \\
\text { reported methods and } \\
\text { sample description. Limited } \\
\text { description of types of activi- } \\
\text { ties undertaken at Old Men: } \\
\text { New Ideas. }\end{array}$ & $18 / 3^{6}$ \\
\hline $\begin{array}{l}\text { Milligan, } \\
\text { Gatrell } \\
\text { and Bingley }\end{array}$ & 2004 & UK & $\begin{array}{l}\text { To assess the health and } \\
\text { wellbeing benefits of } \\
\text { community gardening } \\
\text { for older people. }\end{array}$ & $\begin{array}{l}\text { Ethnographic study of community } \\
\text { gardening activity with older } \\
\text { people supported by qualified } \\
\text { gardener. Study undertaken in } \\
\text { the UK using focus groups and } \\
\text { interviews with participants at start } \\
\text { of project and after nine months. } \\
\text { Supplemented with weekly diaries } \\
\text { from participants along with } \\
\text { regular observational data from } \\
\text { project researcher. }\end{array}$ & $\begin{array}{l}\text { Multiple qualitative } \\
\text { methods give rich } \\
\text { account of replicable } \\
\text { intervention. Strong } \\
\text { on policy needs and } \\
\text { implications regard- } \\
\text { ing healthy ageing. }\end{array}$ & $\begin{array}{l}\text { Relatively small sample size due } \\
\text { to scale of project along with } \\
\text { recruitment and attrition } \\
\text { problems due to poor health. } \\
\text { No comparison group } \\
\text { reported to assess impact of } \\
\text { intervention. }\end{array}$ & $3^{1 / 3^{6}}$ \\
\hline Pretty et al. & 2007 & UK & $\begin{array}{l}\text { To examine the effects of } \\
\text { green exercise in the } \\
\text { UK countryside for } \\
\text { health and psychologi- } \\
\text { cal wellbeing of older } \\
\text { men. }\end{array}$ & $\begin{array}{l}\text { Quantitative study with convenience } \\
\text { sample of older people ( } 55 \% \\
\text { men) participating in green exer- } \\
\text { cise including walking, woodland } \\
\text { conservation and cycling, across } \\
\text { UK. Study used composite ques- } \\
\text { tionnaire with validated measures } \\
\text { designed to assess physical and } \\
\text { mental health, fitness and lifestyle } \\
\text { administered immediately before } \\
\text { and after participation in } \\
\text { activities. }\end{array}$ & $\begin{array}{l}\text { Validated tools measur- } \\
\text { ing mental health } \\
\text { status. Strong on } \\
\text { policy needs and } \\
\text { implications regard- } \\
\text { ing social physical } \\
\text { activity. }\end{array}$ & $\begin{array}{l}\text { Sample of people who were } \\
\text { already active so no data on } \\
\text { the more typical habitually } \\
\text { inactive. Short time-frame for } \\
\text { measuring effects of green } \\
\text { exercise. }\end{array}$ & $34 / 3^{6}$ \\
\hline
\end{tabular}


the lowest categories in hierarchies of research evidence which place greater weight on systematic reviews, randomised controlled trials and well-conducted observational studies (Guyatt et al. 1995).

The studies included contained some quantitative data, predominantly from surveys in mixed-methods papers, but most data were qualitative, offering insights into the perceptions of older men and the processes involved in Men's Sheds and other gendered interventions. Given the preponderance of qualitative data, an interpretive synthesis (Noblit and Hare 1988) approach involving both induction and interpretation was used in both reviews. The four-step guidance on narrative synthesis in reviews (Armstrong et al. 2007; Popay et al. 2006) was used to address the research questions that were posed prior to the review commencing and provide the structure for the findings.

\section{Results}

Of the 14 studies included in the Men's Sheds review, 1 came from Australia (including three on a single study), reflecting the national origin of this form of intervention, along with two studies from the UK and one from Canada. With the exception of a study by Graves (2001), who undertook a mixedmethods, longitudinal evaluation, most of the Australian studies tended to be descriptive and coalesced into either large-scale surveys or small-scale qualitative investigations of particular Sheds. Studies by Milligan et al. (2012, 2014) in the UK and Reynolds (2011) in Canada used mixedmethods approaches involving questionnaires, interviews, focus groups and observations at multiple sites to provide data with richness and depth. In these studies, data collected from older men were supplemented by information from family members and key informants such as project coordinators and health or social care professionals.

Twelve studies were included in the review of other gendered interventions. Four studies originated in Australia, including two by Golding et al. (2009a, $2009 b)$ that were also included in the Sheds review, but also provided insights into alternative activities in communities where Sheds operated. Four studies emanated from the UK, including two on a single intervention in residential care homes in Cornwall, one study came from Norway, one came from Canada and one from the USA. One further study was not clearly geographically located. The types of interventions in these studies were more varied than the Sheds' literature, covering a range of alternative social activities including a cooking club, a community allotment, walking groups and green exercise in the natural environment. The profile of participants was also more varied in terms of age and capability, with some data from employed active men in their 


\section{Christine Milligan}

early fifties who volunteered in their community's emergency response services, to older men in their eighties in residential care who engaged in more sedate activities. In terms of study design, there were cross-sectional studies, often including large-scale surveys supplemented with group interviews; and longitudinal research that used mixed methods to assess the impact of an intervention.

\section{What are the effects on the physical health of older men?}

There was limited evidence of any positive effects on physical health from the studies of Men's Sheds or those of other gendered interventions. Selfreported improvements from participants suggested that such interventions could improve physical health through promoting moderate levels of physical activity, but we found no supporting evidence from more longitudinal studies using objective or validated physical health measures.

\section{What are the effects on the mental health of older men?}

There was more extensive evidence of positive effects on the mental health of those participating in Men's Sheds, compared to people taking part in other social activities. The consistency and frequency of such reports suggests that older men find benefits to their mental health from participating in social and physical activities in Sheds, due to a greater sense of belonging and purpose in their lives.

A similar pattern of self-reported improvements in mental health emerged from the other gendered intervention studies. Both Pretty et al. (2007) and Gleibs et al. (2011) used composite administered research instruments containing questions from validated questionnaires, such as the Profile of Mood States test and the Hospital Anxiety and Depression Scale, to assess mental health status before and after the social activity. Both studies found significant positive effects in terms of improved mental health and wellbeing among participants immediately before and after (Pretty et al. 2007) and over a period of 12 weeks (Gleibs et al. 2011 ). It is notable that despite a commonly held perception that men are reluctant to acknowledge mental health issues, both reviews drew on studies in which older men talked candidly about their own mental health experiences, including feelings of anxiety, depression and even about committing suicide.

\section{What are the effects on the wellbeing of older men?}

There is some evidence of the beneficial effects of Men's Sheds on the social wellbeing of older men. Men's Sheds are socially inclusive spaces that provide participants with a sense of accomplishment, both personal-through 
learning and sharing skills, and social - through contributing to their local community. Sheds also provide a sense of purpose for older men through social engagement with their peers, through enjoyment, and fun (Fildes et al. 2010). Men's Sheds countered social isolation and loneliness by improving feelings of self-esteem and providing social support through the development of friendship and a sense of camaraderie with other men.

\section{What are the effective components of interventions?}

Successful Men's Sheds were in a suitable location, provided a wide range of activities over extended opening hours, enjoyed strong local support and had a skilled co-ordinator who enabled its smooth operation (Milligan et al. 2014).

Men's Sheds are a voluntary activity which operate in relatively unstructured and informal ways that enable older men to choose the activities they will undertake and through this process become 'more than a place to do things but also a place of belonging, friendships and purpose' (Ballinger, Talbot and Verrinder 2009: 26). It is important to note that 'Shedders' tend to view themselves as volunteers or members (rather than clients or patients) who come together, often to give something back to the community, through enjoyable hands-on activities rather than being the recipients of a complex social intervention designed to improve their health and wellbeing.

The other gendered interventions studies offered similar explanations for success in terms of older men coming together and finding a common sense of identity and purpose through shared experiences in volunteer emergency services (Golding et al. 2009b; Hayes, Golding and Harvey 2004) or learning new skills (Golding et al. 2009a; Keller et al. 2004; Milligan, Gatrell and Bingley 2004). The pivotal role of a skilled co-ordinator, usually in a paid position, to provide the organisational skills that enables older men to learn and share skills as well as empowering them to act as co-participants in the operation of an intervention was a common finding in both reviews (Milligan et al. 2012). The friendships and sense of support that can be built over time amongst older men engaged in purposeful voluntary social activities are the foundational building blocks for successful Men's Sheds and other interventions.

\section{What theoretical frameworks were employed?}

A variety of theoretical frameworks were used in the studies to provide an underpinning for analysis and to develop a deeper understanding of why these types of gendered interventions may work. Importantly, the different theoretical approaches used reflect different aspects of the interventions 
that these studies were concerned to draw out, whether that be health, gender, inequalities, identity, learning or a combination of these and/or other issues.

In their study of Men's Sheds, for example, Ballinger, Talbot and Verrinder (2009) used the World Health Organisation's (WHO) Fields of Wellbeing model to inform their research. This model of health is derived from cross-cultural research on people's conceptions and experiences, along with the WHO's definition of health as physical, mental and social wellbeing. It contains six elements that capture the interdependency of health: vitality, positive social relationships, a personal sense of control over one's life and living conditions, enjoyable activities, a sense of purpose and a connectedness to community. Other theoretical frameworks employed included a salutogenic perspective that emphasises factors contributing to health and wellbeing such as a sense of coherence and continuity in life. This theoretical perspective underpinned the purposeful social activities in the rehabilitation centre studied by Batt-Rawden and Tellnes (2005). Gleibs et al. (2011) drew on social identity theory in their studies of older men in residential care. This approach postulates that membership of a social group is critical in forming a shared sense of support through which people are able to understand who they are, and gain the social support they need to protect and enhance their health and wellbeing. Drummond's (2003) study of older men in walking groups conceptualised issues through the lenses of masculinity and phenomenology in order to explore how older men experienced ageing and the steps they took to address it. Finally, (Ballinger, Talbot and Verrinder 2009) used the WHO's Determinants of Disadvantage as a theoretical framework in their studies of Men's Sheds and other types of gendered intervention aimed at older men. This framework identifies a series of factors that underpin the social disadvantages that contribute to health inequalities such as social exclusion, unemployment, difficult experiences earlier in life, the stresses of ageing and the transition from paid work to retirement to develop an explanatory understanding of the circumstances of older men and the scope for effective interventions.

It is worth noting that whilst the variety of theories and frameworks used can reflect different research priorities, it can also make direct comparisons difficult and hinders the identification of the direction of causal pathways between social activity, health and wellbeing.

\section{Critical reflection on included studies}

This review has found evidence to suggest that Men's Sheds and other gendered interventions may have an impact on the mental health and wellbeing 
of older men, but the evidence is not conclusive. There is limited evidence of impact on physical health; and what does exist is largely self-report and limited in scope. Key components of successful interventions included accessibility, range of activities, local support and skilled co-ordination.

Whilst the Men's Sheds literature was relatively homogenous, given it was examining a clearly defined phenomenon, the studies on other gendered interventions were more heterogeneous, covering a wider range of activities stretching from men's cooking clubs to walking groups. The range of activities within the gendered interventions category meant it was more difficult to make generalisable assessments of the impact of these interventions on the health and wellbeing of older men.

The review also identified a limited number and variable quality of studies available for synthesis, reflecting the paucity of interventions aimed at older men. This in itself is an important finding. There was also a preponderance of qualitative studies, and whilst smaller numbers are to be expected in qualitative studies, even taking this into account some studies were based on very small sample sizes. When larger samples were generated, there was often a lack of validated measures in survey instruments and the collection and analysis of qualitative data was not always clearly reported.

Despite the widespread availability and acceptance of objective scales, none of the studies used validated measures to assess physical, or even functional, changes in physical health status. This omission is significant given that some of the Men's Sheds literature asserts that one of the primary benefits of Shed activity is that of participating in physical activities beneficial to health (Ormsby, Stanley and Jaworski 2010). There are selfreported improvements in physical health as a result of the intervention across both the Shed and the other gendered interventions literatures (Milligan et al. 2012), but reporting is limited and needs further verification. Hence, while such evidence should not be dismissed, there is a need for longitudinal and controlled studies that use validated measures of physical health status to provide more reliable evidence to support these selfreported claims that Men's Sheds and other forms of intervention improve the physical health of older men.

Whilst the evidence of benefits to mental health and wellbeing is more consistent across the literature, it too is based largely on low-level studies using a qualitative research design. The mental health benefits of Men's Sheds would benefit from further investigation using validated measures specifically designed to assess mental health status. The methods adopted within some of the research on other gendered interventions (e.g. Gleibs et al. 2011 ) provide a potentially useful guide for further work.

These studies also lacked a control group of older men who did not participate in the organised social activities, making it difficult to be confident 
that self-reported improvements in physical or mental health and social wellbeing were directly attributable to the actual interventions. There is also no evidence about why some older men choose not to participate or, alternatively, initially participated but later withdrew.

Finally, it is worth reflecting that to date, most (though not all) of the Men's Sheds research has been conducted in Australia, some of which has been in rural or remote settings. This raises questions about the need for a deeper understanding of the cultural context within which Sheds have been developed and the extent to which these may need to be adapted for other parts of the world.

\section{Implications of review}

This scoping review has highlighted limitations to the studies on Men's Sheds and other gendered interventions that mean that there is, as yet, no conclusive evidence about their beneficial impact on the health and wellbeing of older men. Qualitative data from these studies provide valuable insights into how and why complex psycho-social interventions affect participants. The sense of identity and purpose in life that older men developed through building friendships and social networks by learning and participating in organised social activities can be difficult to measure but low-level evidence does suggest that it exists.

The wider social wellbeing benefits may be an important element of Men's Sheds, in that they enable older men to share their health concerns and experiences in a supportive environment that is not viewed by participants as being part of the wider health-care system. This more informal 'health by stealth' approach to health promotion amongst older men (Milligan et al. 2012) may be one of the key benefits of Men's Sheds. Misan noted that older men

were less concerned about physical health, and more worried about social, emotional and mental health and wellbeing, about the effects of retirement and about the changing nature of rural communities ... Sheds are important environments in which men offer support to each other on these issues. (2008: 42)

The literature on other gendered interventions was, similarly, generally supportive of improvements in social wellbeing related to participation in social activities that gave older men a 'sense of balance' (Macdonald, Brown and Buchanan 2001) in their lives. This may be important given that older men are at risk of reduced social wellbeing as a result of the transition from paid work into retirement or into residential care - although again the evidence is limited and low level. The study of older men in residential care by Gleibs et al. (2011), although modest in scale, provides some evidence of improved 
social wellbeing and a useful guide for future research. The wider social wellbeing benefits of interventions that provide spaces where older men can stand 'shoulder to shoulder' (Golding and Foley 20o8) have the potential to be considerable but need to be more thoroughly investigated.

The various analytical frameworks used in these studies reflect the variety of academic disciplines and research traditions deployed, but all tend to support the core assumptions of activity theory. They contend that the health and wellbeing of older people is promoted by high levels of engagement in social and leisure activities and role replacement when an established role must be relinquished. The frameworks for further research could include the WHO's Determinants of Disadvantage for men approach that includes domains for social exclusion, unemployment, difficult past lives, the stresses of ageing and substance abuse issues, as used by Golding et al. $(2009 b)$. There is also a case for using the WHO's Fields of Wellbeing approach, as used by Ballinger, Talbot and Verrinder (2009), which explores six dimensions of health and wellbeing.

Further studies of Men's Sheds and other gendered interventions for older men are needed, in order to provide more definitive, generalisable and longitudinal answers to questions about whether there are any measurable effects for physical and mental health that would extend the existing evidence base. Future studies should involve larger samples of participants, consider adopting randomised designs, and deploy mixed methods including standardised measures of health and wellbeing and qualitative approaches.

\section{References}

Arber, S., Perren, K., Daly, T. and Davidson, K. 20o9. Older Men: Their Social Worlds and Healthy Lifestyles. Economic and Social Research Council, Swindon, UK.

Armstrong, R., Waters, E., Jackson, N., Oliver, S., Popay, J., Shepherd, J., Petticrew, M., Anderson, L., Bailie, R., Brunton, G., Hawe, P., Kristjansson, E., Naccarel la, L., Norris, S., Pienaar, E., Roberts, H., Rogers, W., Sowden, A. and Thomas, H. 2007. Guidelines for Systematic Reviews of Health Promotion and Public Health Interventions. Version 2, Melbourne University, Melbourne.

Australian Government Department of Health (2015) Australian Government Shed Development Program. Available at: http://www.health.gov.au/internet/main/ publishing.nsf/Content/male-health-programs\#sheds [accessed o8/01/15]

Ballinger, M. L., Talbot, L. A. and Verrinder, G. K. 2009. More than a place to do woodwork: a case study of a community-based Men's Shed. Journal of Men's Health, 6, 1, 20-7.

Batt-Rawden, K. and Tellnes, G. 2005. Nature-culture-health activities as a method of rehabilitation: an evaluation of participants' health, quality of life and function. International Journal of Rehabilitation Research, 28, 2, $175^{-80 .}$

Betts Adams, K., Leibbrandt, S. and Moon, H. 2011 . A critical review of the literature on social and leisure activity and wellbeing in later life. Ageing $\mathcal{E}$ Society, 31 , 4, 683-7. 
Buss, M. 1999. Evolutionary psychology: The new science of the mind. Allyn and Bacon, Boston, MA: Allyn \& Bacon.

Cacioppo, J. T., Hawkley, L. C., Norman, G. J. and Berntson, G. G. 2011. Social isolation. Annals of the New York Academy of Sciences, 1231, 1, 17-22.

Carragher, L. 2013. Men's Sheds in Ireland: Learning Through Community Contexts. Research Report. Available online at http://menssheds.ie/m/wp-content/ uploads/2013/10/Men's-Sheds-in-Ireland-National-Survey.pdf [Accessed 30 January 2014].

Cass, Y., Fildes, D. and Marshall, C. 2008. 3 in 1 - Mature men's project evaluation results. Centre for Health Service Development, South-eastern Sydney Illawarra, Australia. Available online at: http://www.healthyillawarra.org.au/healthypeople/ docs/3inımen.pdf [Accessed 9/01/15]

Cattan, M., Newell, C., Bond, J. and White, M. 2003. Alleviating social isolation and loneliness among older people. International Journal of Mental Health Promotion, 5, 3, 20-30.

Cordier, R. and Wilson, N. 2014. Mentoring at Men's Sheds: an international survey about a community approach to health and well-being. Health and Social Care in the Community, 22, 3, 249-58.

Craig, P., Dieppe, P., Macintyre, S., Mitchie, S., Nazareth, I. and Petticrew, M. 2008. Developing and evaluating complex interventions: the new Medical Research Council guidance. British Medical Journal, 337, 1655 .

Davidson, K. 2013. Older men in the community: a UK perspective. In Phellas, C. (ed.), Aging in European Societies, International Perspectives on Aging. Book Series 6, Springer, New York, ${ }^{16} 63-76$.

Dickens, A. P., Richards, S. H., Greaves, C. J. and Campbell, J. L. 2011 . Interventions targeting social isolation in older people: a systematic review. BMC Public Health, $\mathbf{1} 1,647-59$.

Drummond, M.J. 2003. Retired men, retired bodies. International Journal of Men's Health, 3, 2, $183-98$.

Eurostat 201 2. Mortality and Life Expectancy Statistics. Available online at http://epp. eurostat.ec.europa.eu/statistics_explained/index.php/Mortality_and_life_expectancy_ statistics\#The_gender_gap_is_shrinking [Accessed 17 January 2014].

Fennell, G. and Davidson, K. 2003. The invisible man? Older men in modern society. Ageing International, 28, 4, 31 $5^{-2} 5$.

Fildes, D., Cass, Y., Wallner, F. and Owen, A. 2010. Shedding light on men: the Building Healthy Men Project. Journal of Men's Health, 7, 3, 233-40.

Findlay, R. A. 2003. Interventions to reduce social isolation amongst older people: where is the evidence? Ageing $\mathcal{E}^{2}$ Society, 23, $5,647^{-} 5^{8}$.

Fleming, A. 1999. Older men in contemporary discourses on ageing: absent bodies and invisible lives. Nursing Inquiry, 6, 1, 3-8.

Gleibs, I., Sonneberg, S., Haslam, C., Jones, J., Haslam, A., McNeill, J. and Connolly, H. 2011. No country for old men? The role of a 'Gentlemen's Club' in promoting social engagement and psychological well-being in residential care. Aging and Mental Health, $\mathbf{1 5}, 4,45^{6-66 .}$

Golding, B. 2011 . Older men's wellbeing through community participation in Australia. International Journal of Men's Health, 10, 1, 26-44.

Golding, B., Harvey, J., Foley, A., Brown, M. and Darken, S. 20o6. Final report on a survey of men's sheds participants in Victoria. Adult, Community and Further Education Board, Melbourne, Australia.

Golding, B., Brown, M. and Foley, A. 2007. Old dogs new shed tricks. An exploration of innovative workshop-based practice for older men in Australia. Australian Vocational Education and Training Research Association (AVETRA) Conference. 
Melbourne, Australia. Available online at https://avetra.org.au/documents/2 1Golding.pdf [Accessed 9/01/15]

Golding, B., Brown, M., Foley, A., Harvey, J. and Gleeson, L. 2007. Men's sheds in Australia. Learning through community contexts. National Centre for Vocational Education Research, (NCVER), Adelaide, Australia. Available online at http://www.omal.si/userfiles/file/Learning_through_community_contexts. pdf [Accessed 9/01/15].

Healthbox Community Interest Company 201 2. Men in Sheds programme health evaluation. Age UK, Cheshire, UK.

Golding, B., Brown, M., Foley, A. and Harvey, J. 2009 $a$. Mens learning and wellbeing through community organisations in Western Australia. Report to Western Australia Department of Education and Training, School of Education, Federation University, Perth, Australia.

Golding, B. and Foley, A. 2008. 'How men are worked with': gender roles in men's informal learning. Paper presented to the 38 th Annual SCUTREA Conference, 24 July, Edinburgh, UK.

Golding, B., Foley, A., Brown, M. and Harvey, J. 20ogb. Senior Men's Learning and Wellbeing Through Community Participation in Australia. Report to the National Seniors Productive Ageing Centre, School of Education, Federation University, Perth, Australia. Available online at http://www.productiveageing.com.au/site/ research.php [Accessed 17 January 2014].

Graves, K. 2001. Shedding the Light on Men in Sheds: Final Report 20or. Community Health, Bendigo, Australia.

Greenfield, E. and Marks, N. 2004. Formal volunteering as a protective factor for older adults' psychological well-being. Journal of Gerontology, 59, 5, 258-64.

Guyatt, G. H., Sackett, D. L., Sinclair, J. C., Hayward, R., Cook, D. J. and Cook, R. J. 1995. Users' guides to the medical literature. IX. A method for grading health care recommendations. Evidence-Based Medicine Working Group. JAMA, 274, $22,1800-4$.

Hawker, S., Payne, S., Kerr, C., Hardey, M. and Powell, J. 2002. Appraising the evidence: reviewing disparate data systematically. (Qualitative Health Research, 12, 9, 1284-99. DOI: $10.1177 / 1049732302238251$ (C2002 Sage Publications)

Hawton, A., Green, C., Dickens, A., Richards, S., Taylor, R., Edwards, R., Greaves, C. J. and Campbell, J. L. 2011. The impact of social isolation on the health status and health-related quality of life of older people. Quality of Life Research, 2o, 1, $57-67$.

Hayes, C., Golding, B. and Harvey, J. 2004. Adult Learning Through Fire and Emergency Service Organisations in Small and Remote Australian Towns. National Council for Vocational Education Research, Adelaide, Australia.

Healthbox Community Interest Company. 2012. Men in Sheds Programme Health Evaluation. Age UK, Cheshire, UK.

Holt-Lunstad, J., Smith, T. B. and Layton, J. B. 2010. Social relationships and mortality risk: a meta-analytic review. PLOS Medicine, 7, 7, e1000316. doi:10.1371/ journal.pmed.1000316.

House, J., Landis, K. and Umberson, D. 1988. Social relationships and health. Science, New Series, 241, $4865,540-5$.

Iliffe, S., Kharicha, K., Harari, D., Swift, C., Gillmann, G. and Stuck, A. E. 2007. Health risk appraisal in older people 2: the implications for clinicians and commissioners of social isolation risk in older people. British Journal of General Practice, $\mathbf{5 7}$, $537,277-82$.

Keller, H., Gibbs, A., Wong, S.,Vanderkooy, P. and Hedley, M. 2004. Men can cook! Journal of Nutrition for the Elderly, 24, 1, 7 1-87. 
Luanaigh, C. O. and Lawlor, B. A. 2008. Loneliness and the health of older people. International Journal of Geriatric Psychiatry, 23, 12, $1213^{-2} 1$.

Macdonald, J., Brown, A. and Buchanan, J. 2001. Keeping the Balance: Older Men and Healthy Ageing. A Framework for Discussion. New South Wales Committee on Ageing and the Men's Health Information and Resource Centre, University of Western Sydney, Sydney.

Masi, C. M., Chen, H., Hawkley, L. C. and Cacioppo, J. T. 2011. A meta-analysis of interventions to reduce loneliness. Journal of Investigative Medicine, 59, 4, 71 1-2.

Medical Research Council 2008. Medical Research Council Guidance on Complex Interventions. Prepared by Craig, P., Dieppe, P., Macintyre, S., Mitchie, S., Nazareth, I. and Petticrew, M. Medical Research Council, UK. Available online at http://www.mrc.ac.uk/documents/pdf/complex-interventions-guidance/ [Accessed 9 December 2014].

Milligan, C., Gatrell, A. and Bingley, A. 2004. Cultivating health: therapeutic landscapes and older people in northern England. Social Science and Medicine, 58, $1781-93$.

Milligan, C., Payne, S., Bingley, A. and Cockshott, Z. 201 2. Evaluation of the men in sheds pilot programme. Report for Age UK, London.

Milligan, C., Payne, S., Bingley, A. and Cockshott, Z. 2014. Gender, place and health: shedding light on activity interventions for older men. Ageing $\mathcal{E}$ Society, 35, $1,124-49$.

Misan, G. 2008. Men's Sheds: a strategy to improve men's health. Report for Mensheds Australia, Spencer Gulf Rural Health School, Adelaide, Australia.

Noblit, G. and Hare, R. 1988. Meta-ethnography: Synthesizing Qualitative Studies. Sage, Beverley Hills, California.

Ormsby, J., Stanley, M. and Jaworski, K. 2010. Older men's participation in communitybased men's sheds programmes. Health and Social Care in the Community, 18, 6, $607-13$.

Pantell, M., Rehkopf, D., Jutte, D. S., Syme, L., Balmes, J. and Adler, N. 2013. Social isolation: a predictor of mortality comparable to traditional clinical risk factors. American Journal of Public Health, 103, $11,205^{6-62 . ~}$

Popay, J., Roberts, H., Sowden, A., Petticrew, M., Arai, L., Rodgers, M., Britten, N., Roen, K. and Duffy, S. 20o6. Guidance on conducting narrative synthesis in systematic reviews. Methods Briefing 22, Cathie Marsh Institute for Social Research, Manchester, UK.

Pretty, J., Peacock, J., Hine, R., Sellens, M., South, N. and Griffin, M. 2007. Green exercise in the UK countryside: effects on health and psychological well-being, and implications for policy and planning. Journal of Environmental Planning and Management, 50, 2, $211-31$.

Reynolds, K. A. 2011 . Older male adults' involvement in mens sheds. Master of Arts Thesis, University of Manitoba, Winnipeg, Manitoba, Canada.

Salomon, J., Wang, H., Freeman, T., Flaxman, A., Lopez, A. and Murray, C. 2012. Healthy life expectancy for 187 countries, 1990-2010: a systematic analysis for the Global Burden Disease Study 2010. Lancet, 380, 3859, $2144^{-62}$.

Shankar, A., McMunn, A., Banks, J. and Steptoe, A. 201 1. Loneliness, social isolation, and behavioral and biological health indicators in older adults. Health Psychology, 3o, 4, 377-85.

Steffick, D. E. 200o. Documentation of affective functioning measures in the Health and Retirement Study. HRS/AHEAD Documentation Report, University of Michigan, Ann Arbor, Michigan.

Suominen-Taipale, A., Martelin, T., Koskinen, S., Holmen, J. and Johnsen, R. 2006. Gender differences in health care use among the elderly population in areas of 
Norway and Finland. A cross-sectional analysis based on the HUNT study and the FINRISK Senior Survey. BMC Health Services Research, 6, 1, 110.

Victor, C. R., Scambler, S. and Bond, J. 2009. The Social World of Older People: Understanding Loneliness and Social Isolation in Later Life. Open University Press/ McGraw Hill Education, Maidenhead, UK.

Wang, H., Dwyer-Lindgren, L., Lofgren, K., Knoll Rajaratnam, J., Marcus, J., LevinRector, L., Levitz, C., Lopez, A. and Murray, C. 2012. Age-specific and sexspecific mortality in 187 countries, 1970-2010: a systematic analysis for the Global Burden of Disease Study 201 2. Lancet, 38o, 9859, 2071-94.

White, A., de Sousa, B., de Visser, R., Hogston, R., Aage Madsen, S., Makara, P., Richardson, N. and Zatonski, W. 2011. The state of men's health in Europe. Extended Report, European Commission Directorate-General for Health and Consumers, Brussels.

Wilson, N.J. and Cordier, R. 2013. A narrative review of Men's Sheds literature: reducing social isolation and promoting men's health and well-being. Health and Social Care in the Community, 21, 5, 45 1-63.

\section{Accepted I5 December 20I4; first published online 5 March 2015}

Address for correspondence.

Christine Milligan,

Centre for Ageing Research,

Faculty of Health and Medicine,

Lancaster University,

Bailrigg, Lancaster, UK

E-mail: c.milligan@lancaster.ac.uk 